\title{
The first record of Elodea nuttallii (Hydrocharitaceae) in the Lower Dnipro River
}

\author{
Anastasia O. DAVYDOVA ${ }^{1,3 *}$ (D), Kateryna S. ORLOVA-HUDIM ${ }^{2,3,4}$ (D), Ivan V. SHEVCHENKO ${ }^{2,3}$ (D), \\ Denys A. DAVYDOV ${ }^{1}$ (D), Viktoria M. DZERKAL ${ }^{3}$ \\ ${ }^{1}$ M.G. Kholodny Institute of Botany, National Academy of Sciences of Ukraine, 2 Tereschenkivska Str., Kyiv 01601, Ukraine \\ ${ }^{2}$ Kherson Hydrobiological Station of NAS of Ukraine, 87 Maria Fortus Str., Kherson 73016, Ukraine \\ ${ }^{3}$ Nyzhniodniprovskyi National Nature Park, 18 Petrenko Str., Kherson 73000, Ukraine \\ ${ }^{4}$ Kherson State University, 27 Universitetska Str., Kherson 73003, Ukraine
}

\begin{abstract}
Six localities of Elodea nuttallii were found in 2020 in the Lower Dnipro River (Kherson Region) within the territory of Nyzhniodniprovskyi National Nature Park. These are the first verified records of this alien aquatic plant (native to North America) in the Steppe Zone of Ukraine. Previously, it has been reported in Ukraine only from the Forest (Kyiv city) and Forest-Steppe (Kyiv, Poltava and Cherkasy administrative regions) zones. Geographic coordinates, depths and substrate are reported for all found localities. Geobotanical data about this species in Ukraine are summarized. It is assumed that Elodea nuttallii as a potentially invasive species in this region may occur not only in the Lower Dnipro River but also in all reservoirs on this river.
\end{abstract}

Keywords: alien species, Elodea, floristic find

Article history. Submitted 20.10.2020. Revised 24.07.2021. Published 30.08.2021

Citation. Davydova A.O., Orlova-Hudim K.S., Shevchenko I.V., Davydov D.A., Dzerkal V.M. 2021. The first record of Elodea nuttallii (Hydrocharitaceae) in the Lower Dnipro River. Ukrainian Botanical Journal, 78(4): 303-307. https:// doi.org/10.15407/ukrbotj78.04.303

*Corresponding author (e-mail: anasta3Kz@gmail.com)

Elodea nuttallii (Planch.) H.St.John (basionym Anacharis nuttallii Planch.) is a perennial submerged aquatic plant described from North America and at present distributed mostly in mid- and north-eastern USA and Canada (St. John, 1920; Simpson, 1984). It is an alien species in Europe first reported from Belgium in 1939 (Simpson, 1984). Found also in Great Britain in 1966, currently this plant is distributed in fresh or brackish waters in many other European countries, including Austria, Belarus, Bulgaria, Croatia, Czech Republic, Denmark, France, Hungary, Italy, Ireland, Germany, Luxembourg, Netherlands, Romania, Russian Federation, Serbia, Slovakia, Slovenia, Sweden, and Switzerland (Simpson, 1984; Escobar et al., 2011; Hussner, 2012; Kočić et al.,
2014; Panasenko, Shcherbakov, 2018). Outside Europe, it was reported from Japan (Kunii, 1984), Philippines and China (Wang et al., 2016).

In Ukraine, Elodea nuttallii was first reported from a bay of the Kaniv Reservoir on the Dnipro River("Kuriache Horlo" boundary) in 2004 and one year later - in a bay of the Dnipro River near Tsybli village (both locations are now in Boryspil District, Kyiv Region) by Chorna, Protopopova, Shevera, and Fedoronchuk (Chorna et al., 2006). In 2012, E. nuttallii was reported by Starovoytova (2011) in the Lower Sula River near Demyanivka village (Kremenchuk District, Poltava Region). Two recent papers of Prokopuk and Zub $(2019 ; 2020)$ provide morphological features of species of the genus Elodea

(C) 2021 A.O. Davydova, K.S. Orlova-Hudim, I.V. Shevchenko, D.A. Davydov, V.M. Dzerkal. Published by the M.G. Kholodny Institute of Botany, NAS of Ukraine. This is an open access article under the terms of the Creative Commons Attribution License (http://creativecommons.org/licenses/ by/4.0/), which permits use, distribution, and reproduction in any medium, provided the original work is properly cited 


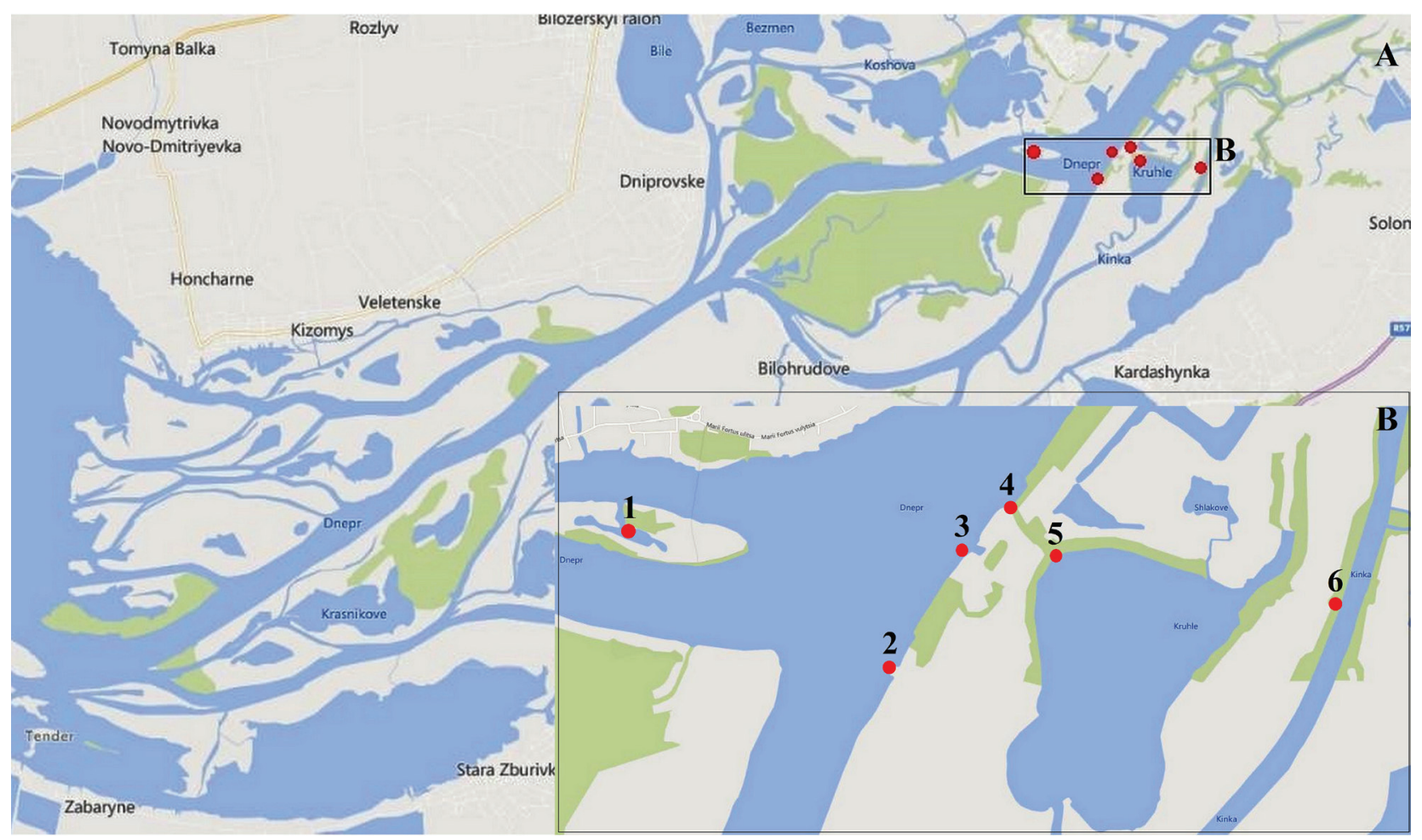

Fig. 1. Schematic map of new localities of Elodea nuttallii in the Lower Dnipro River

Table 1. Localities of Elodea nuttallii in the Lower Dnipro River

\begin{tabular}{|c|c|c|c|c|c|c|}
\hline \multirow{2}{*}{ No } & \multirow{2}{*}{ Locality } & \multicolumn{2}{|c|}{ Coordinates } & \multirow{2}{*}{$\begin{array}{c}\text { Depth, } \\
\mathrm{m}\end{array}$} & \multirow{2}{*}{ Substrate } & \multirow{2}{*}{ Date } \\
\hline & & Latitude $(\mathrm{N})$ & Longitude (E) & & & \\
\hline 1 & Lebedyne Lake & $46^{\circ} 35^{\prime} 55.3^{\prime \prime}$ & $32^{\circ} 34^{\prime} 16.3^{\prime \prime}$ & 0.5 & silted sand & 30.09 .2020 \\
\hline 2 & \multirow{2}{*}{ The Dnipro River } & $46^{\circ} 35^{\prime} 35.0^{\prime \prime}$ & $32^{\circ} 35^{\prime} 25.5^{\prime \prime}$ & $6-7$ & \multirow{2}{*}{ silted sand } & 13.07.2020, \\
\hline 3 & & $46^{\circ} 35^{\prime} 52.8^{\prime \prime}$ & $32^{\circ} 35^{\prime} 40.5^{\prime \prime}$ & $3-4$ & & 17.08 .2020 \\
\hline 4 & Strait to Krugle Lake & $46^{\circ} 35^{\prime} 58.6^{\prime \prime}$ & $32^{\circ} 35^{\prime} 54.3^{\prime \prime}$ & $1.5-2.3$ & sandy silt & $\begin{array}{c}17.08 .2020 \\
14.09 .2020\end{array}$ \\
\hline 5 & Krugle Lake & $46^{\circ} 35^{\prime} 50.0^{\prime \prime}$ & $32^{\circ} 36^{\prime} 03.8^{\prime \prime}$ & $1.8-2.5$ & sandy silt & $\begin{array}{l}17.08 .2020 \\
14.09 .2020\end{array}$ \\
\hline 6 & Strait to the Konka River & $46^{\circ} 35^{\prime} 44.1^{\prime \prime}$ & $32^{\circ} 37^{\prime} 16.8^{\prime \prime}$ & $0.7-1.0$ & sandy silt & 14.09 .2020 \\
\hline
\end{tabular}

Rich. in Ukraine and their current distribution. The authors reported 22 new sites for E. nuttallii: Babyne, Verkhnie Vyhurivske, Berizka, Sribnyi Kil, Yaremyne, Nebrezh and Martyshyv lakes, a lake in Zhukiv Ostriv Landscape Reserve, Halerna and Domania loughs, the mouth of the Vita River, the Desenka and Bobrovnia rivers (Kyiv city), a channel of the Bortnychi aeration station (Boryspil District, Kyiv Region), Kaniv Reservoir near Kyiliv village (Boryspil District, Kyiv Region), the Krasna River in Trypillia village and the Bobrytsia River in Khalepye village (Obukhiv District, Kyiv Region), the Nedra River in Berezan town (Brovary District, Kyiv Region), the mouth of the Trubizh River in Pereyaslav town (Boryspil District, Kyiv Region), the Dnipro River near Pekari and Prokhorivka villages and the
Kremenchuk Reservoir near Shelestiv Island in Kaniv Nature Reserve (Cherkasy District, Cherkasy Region) (Prokopuk, Zub, 2019; Zub, Prokopuk, 2020). Thus, all confirmed locations of Elodea nuttallii within Ukraine are located in the Forest (Kyiv city) and the Forest-Steppe (Kyiv, Poltava and Cherkasy regions) nature zones. For the Steppe Zone, only one record from the mouth of the Danube River (Dubyna et al., 2017) was reported. A recent record of E. nuttallii in Sevastopol, Crimea was published (Svirin et al., 2021).

During the investigation of aquatic vegetation of Nyzhniodniprovskyi National Nature Park in Kherson Region in 2020, Elodea nuttallii was found in six localities (Fig. 1).

Detailed data about our findings are summarized in Table 1.

Ukrainian Botanical Journal, 2021, 78(4) 


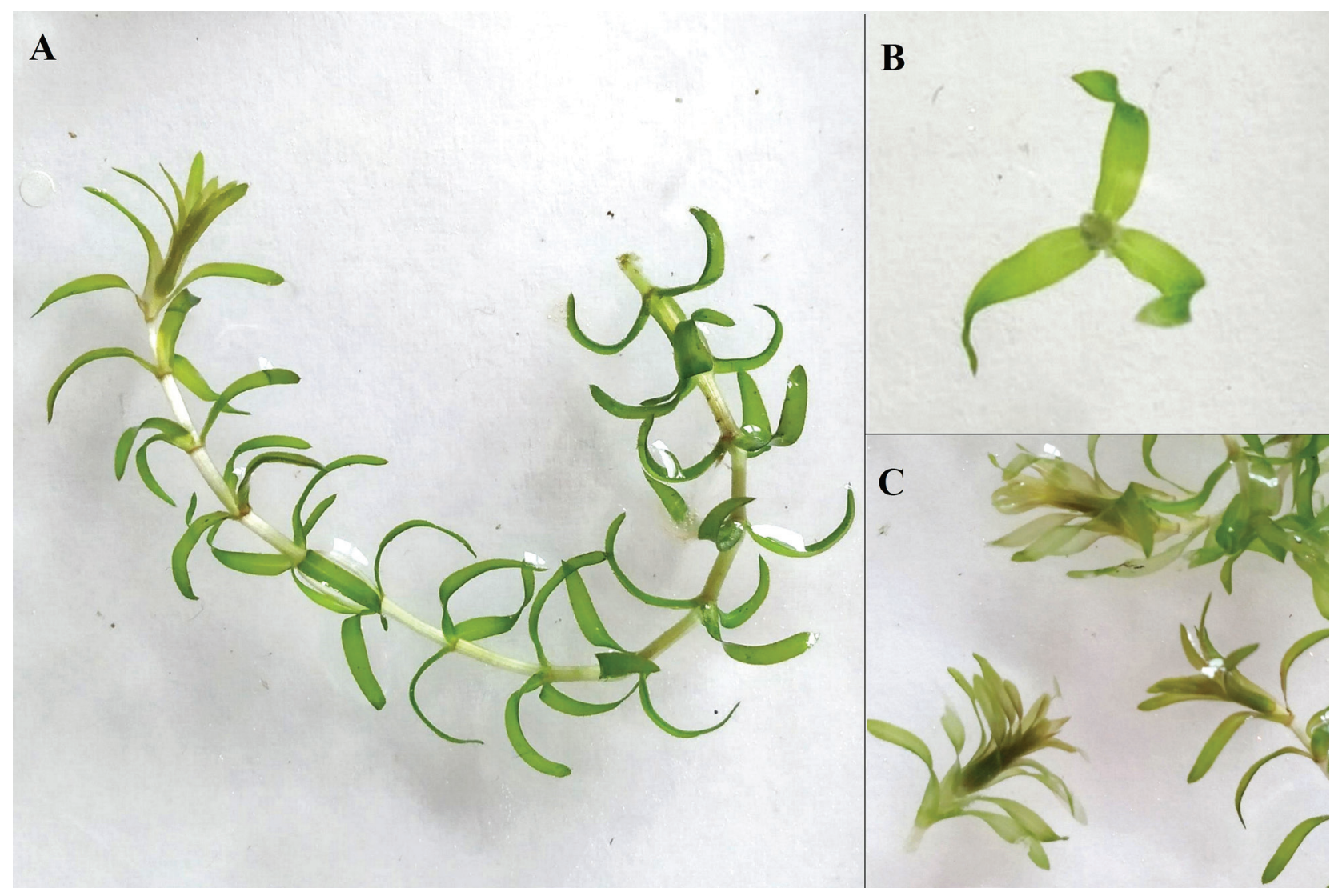

Fig. 2. Elodea nuttallii. A: a part of the plant; B: a leaf whorl; C: upper parts of stems

Our findings are not limited to the mentioned points with coordinates, since $E$. nuttallii is common between localities 1, 2 and 3, it occurs in all areas along a strait to Kruhle Lake (3) and in several areas along shores of Kruhle Lake (4) (Table 1).

Morphological characters of Elodea nuttallii are described in detail in many sources (St. John, 1920, 1965; Haynes, 2000; Chorna et al., 2006; Kočić et al., 2014). The main differences between Elodea nuttallii and Elodea canadensis Michx. are the width of a leaf measured at the point approximately $0.5 \mathrm{~mm}$ below the apex, the width/length ratio and the angle at the apex. In E. canadensis, leaves are shorter and wider, the width/ length ratio is higher and the angle at the leaf apex it is within a range $50-60^{\circ}$, in the upper part of a stem leaves usually lying along and overlapping in rows.

Leaves of the plants we observed are in whorls of three, recurved, linear to lanceolate with undulate margins (Fig. 2). The leaf width at the mid-point are $1.2-1.6 \mathrm{~mm}$ and at $0.5 \mathrm{~mm}$ below the tip $-0.57-0.62$ $\mathrm{mm}$, leaf length are $9.2-13.1 \mathrm{~mm}$ ), the width/length ratio is 0.14 , the angle at the apex is $31-34^{\circ}$. In our opinion, climatic conditions and geobotanical data for the studied localities of $E$. nuttallii provide additional information and may be used by other authors in further research.

Climatic conditions. According to the meteorological journal of the Kherson Hydrobiological Station of the National Academy of Sciences of Ukraine, during the last 10 years the average water temperature in the Lower Dnipro River was $14.4^{\circ} \mathrm{C}$ (the coldest in February $-1.4^{\circ} \mathrm{C}$, the warmest in July $-26.1^{\circ} \mathrm{C}$ ). During the winter period the average water temperature is $2.8^{\circ} \mathrm{C}$.

Geobotanical characteristics. In the Lower Dnipro River, Elodea nuttallii formed aquatic communities belonging to the class Potamogetonetea Klika in Klika et Novák 1941 with poor species composition (2-5 species on plots of $5 \times 5 \mathrm{~m}$ ). The species characteristic of deeper plots (6-7 $\mathrm{m}$ deep) is Potamogeton perfoliatus L., on shallowerareas-Ceratophyllum demersum L., Vallisneria spiralis L. and the underwater form of Nuphar lutea (L.) Sm. Starovoytova (2012) described communities with 
E. nuttallii and another alien aquatic species E. densa (Planch.) Caspari (= Egeria densa Planch.) from the Lower Sula River as the new association Egerio densaeElodeetum nutalliae Starovoytova 2012, but this name is invalid according to Art. 5 of the International Code of Phytosociological Nomenclature (Theurillat et al., 2021); besides, Elodea densa has previously never been found in the Lower Dnipro River. Dubyna with coauthors (2017) mentioned for Ukraine three associations (Polygono-Potametum natantis Soó 1957, Potametum lucentis Hueck 1931 and Potametum crispi Soó 1927) with $E$. nuttallii as an attendant species, and two syntaxa with $E$. nuttallii as a diagnostic and characteristic taxon - Elodeetum nuttallii Ciocorlan et al. 1997 and Ceratophyllo demersi-Elodeetum nuttallii Ciocorlan et al. 1997 (Dubyna et al., 2017). However, these two syntaxa described from Romania have not been listed in the Prodrome of the vegetation of Ukraine (Dubyna et al., 2019) so their presence in Ukraine needs further confirmation.

The reported localities in the territory of Nyzhniodniprovskyi National Nature Park in Kherson Region are the first verified records of Elodea nuttallii in the Steppe Zone of Ukraine. These localities were confirmed by two herbarium specimens in the Nyzhniodniprovskyi National Nature Park and three observations with photographs on iNaturalist (available at: https://www.inaturalist.org/observations/57640327; https://www.inaturalist.org/observations/57807094, and https://www.inaturalist.org/observations/57807189).

Thus, our results confirmed the distribution of the alien aquatic species Elodea nuttallii in the Lower Dnipro River (Kherson Region). It is potentially an invasive species in this region. Therefore it is necessary to explore the aquatic vegetation of all reservoirs on the Dnipro River within the Steppe Zone of Ukraine in order to obtain more data about the current distribution of this species in Ukraine.

\section{Acknowledgements}

We are grateful to Andrey Efremov (Omsk State Pedagogical University, Omsk, Russian Federation) and Dariusz Kamiński (Nicolaus Copernicus University, Torun, Poland) who confirmed our observations of Elodea nuttallii on iNaturalist and made valuable comments about these findings.

\section{References}

Chorna G.A., Protopopova V.V., Shevera M.V., Fedoronchuk M.M. 2006. Ukrainian Botanical Journal, 63(3): 328-332. [Чорна Г.А., Протопопова В.В., Шевера М.В., Федорончук М.М. 2006. Elodea nuttallii (Planch.) St. John (Hydrocharitaceae) - новий для флори України вид. Український ботанічний журнал, 63(3): 328-332].

Dubyna D.V., Dzyuba T.P., Dvoretsky T.V., Zolotareva O.K., Taran N.Yu., Mosyakin A.S., Yemelyanova S.M., Kazarinova G.O. 2017. Ukrainian Botanical Journal, 74(3): 248-262. [Дубина Д.В., Дзюба Т.П., Дворецький Т.В., Золотарьова О.К., Таран Н.Ю., Мосякін А.С., Ємельянова С.М., Казарінова Г.О. 2017. Інвазійні водні макрофіти України. Український ботанічний журнал, 74(3): 248-262]. https://doi. org/10.15407/ukrbotj74.03.248

Dubyna D.V., Dziuba T.P., Iemelianova S.M., Bagrikova N.O., Borysova O.V., Borsukevych L.M., Vynokurov D.S., Gapon S.V., Gapon Yu.V., Davydov D.A., Dvoretskyi T.V., Didukh Ya.P., Zhmud O.I., Kozyr M.S., Konishchuk V.V., Kuzemko A.A., Pashkevych N.A., Ryff L.E., Solomakha V.A., Felbaba-Klushyna L.M., Fitsailo T.V., Chorna H.A., Chorney I.I., Shelyag-Sosonko Yu.R., Iakushenko D.M. 2019. Prodrome of the Vegetation of Ukraine. Eds D.V. Dubyna, T.P. Dziuba. Kyiv: Naukova Dumka, 782 pp. [Дубина Д.В., Дзюба Т.П., Смельянова С.М., Багрікова Н.О., Борисова О.В., Борсукевич Л.М., Винокуров Д.С., Гапон С.В., Гапон Ю.В., Давидов Д.А., Дворецький Т.В., Дідух Я.П., Жмуд О.І., Козир М.С., Конішук В.В., Куземко А.А., Пашкевич Н.А., Рифф Л.Е., Соломаха В.А., ФельбабаКлушина Л.М., Фіцайло Т.В., Чорна Г.А., Чорней I.I., Шеляг-Сосонко Ю.Р., Якушенко Д.М. 2019. Продромус рослинності України. Відп. ред. Д.В. Дубина, Т.П. Дзюба. Київ: Наукова думка, 784 с.].

Escobar M.M., Voyevoda M., Fühner C., Zehnsdorf A. 2011. Potential uses of Elodea nuttallii harvested biomass. Energy, Sustainability and Society, 1(4): 1-8. https://doi. org/10.1186/2192-0567-1-4

Haynes R.R. 2000. Elodea. In: Flora of North America Editorial Committee (eds.). Flora of North America north of Mexico, vol. 22. New York; Oxford: Oxford University Press, pp. 32-34. Available at: http://www.efloras.org/ florataxon.aspx?flora id=1\&tax on id=222000059 (Accessed 20 July 2021).

Hussner A. 2012. Alien aquatic plant species in European countries. Weed Research, 52: 297-306. https://doi. org/10.1111/j.1365-3180.2012.00926.x

Kočić A., Horvatić J., Jelaska S. 2014. Distribution and morphological variations of invasive macrophytes Elodea nuttallii (Planch.) H.St.John and Elodea canadensis Michx in Croatia. Acta Botanica Croatica, 73(2): 437-446. https://doi.org/10.2478/botcro-2014-0011

Kunii H. 1984. Seasonal growth and profile structure development of Elodea nuttallii (Planch.) St. John. in pond Ojaka-Ike, Japan. Aquatic Botany, 18: 239-247. https:// doi.org/10.1016/0304-3770(84)90065-2 
Panasenko N.N., Shcherbakov A.V. 2018. Bulletin of Moscow Society of Naturalists. Biological series, 123 (6): 5859. [Панасенко Н.Н., Щербаков А.В. 2018. Elodea nuttallii (Planch.) H.St.John (Hydrocharitaceae) - новый потенциально инвазионный вид для флоры России. Бюллетень Московского общества испытателей природы. Отдел биологический, 123(6): 58-59].

Prokopuk M., Zub L. 2019. Peculiarities of species of Elodea (Hydrocharitaceae) in the aquatic ecosystems of Ukraine (East Europe). Phytologia Balcanica, 25(3): 381-386.

Simpson D.A. 1984. A short history of the introduction and spread of Elodea Michx. in the British Isles. Watsonia, 15: $1-9$.

St. John H. 1920. The genus Elodea in New England. Rhodora, 22: 17-29.

St. John H. 1965. Monograph of the genus Elodea, part 4: The species of Eastern and Central North America. Rhodora, 67: $1-35$.

Starovoytova M.Yu. 2011. Scientific reports of NULES of Ukraine, 5(27): 1-10. Available at: Available at: https:// nd.nubip.edu.ua/2011 5/11smy.pdf. [Старовойтова М.Ю. 2011. Родина Hydrocharitaceae у флорі річки Сули та їі приток. Наукові доповіді НУБіП, 5(27): 1-10].

Starovoytova M.Yu. 2012. Bulletin of Taras Shevchenko National University. Series Introduction and conservation of plant diversity, 1(30): 45-48. [Старовойтова М.Ю.
2012. Поширення та еколого-ценотична характеристика видів Egeria densa Planchon та Elodea nutallii (Planch) у водоймах басейну р. Сули. Вісник КНУ імені Тараса Шевченка. Серія Інтродукиія та збереження рослинного різноманіття, 1(30): 45-48].

Svirin S.A., Lyamina N.V., Yena A.V. 2021. Elodea nuttallii. In: Raab-Straube E. von, Raus Th. (ed.). Euro+Med-Checklist Notulae, 13 [Notulae ad floram euro-mediterraneam pertinentes No. 42]. Willdenowia, 51: 150-151. https://doi. org/10.3372/wi.51.51112

Theurillat J.-P., Willner W., Fernández-González F., Bültmann H., Čarni A., Gigante D., Mucina L., Weber H. 2021. International Code of Phytosociological Nomenclature. $4^{\text {th }}$ ed. Applied Vegetation Science, 24(1): 1-62. https://doi.org/10.1111/avsc.12491

Wang H., Wang Q., Bowler P.A., Xiong W. 2016. Invasive aquatic plants in China. Aquatic Invasions, 11(1): 1-9. http://dx.doi.org/10.3391/ai.2016.11.1.01

Zub L.N., Prokopuk M.S. 2020. Russian Journal of Biological Invasions, 1: 8-19. [Зуб Л.Н., Прокопук М.С. 2020. Особенности инвазий макрофитов в водные экосистемы Среднего Приднепровья (Украина). Российский журнал биологических инвазий, 1: 8-19].

Recommended for publication by G.V. Boiko

Давидова А.О., Орлова-Гудім К.С., Шевченко І.В., Давидов Д.А., Дзеркаль В.М. 2021. Перші знахідки Elodea nuttallii (Hydrocharitaceae) у пониззі Дніпра. Український ботанічний журнал, 78(4): 303-307 [In English].

Інститут ботаніки ім. М.Г. Холодного НАН України, вул. Терещенківська 2, Київ 01601, Україна: А.О. Давидова, Д.А. Давидов. Херсонська гідробіологічна станція НАН України, вул. Марії Фортус 87, Херсон 73016, Україна: К.С. Орлова-Гудім, І.В. Шевченко. Національний природний парк "Нижньодніпровський", вул. Петренко 18, Херсон 73000, Україна: К.С. Орлова-Гудім, І.В. Шевченко, В.М. Дзеркаль, А.О. Давидова. Херсонський державний університет, вул. Університетська 27, Херсон 73003, Україна: К.С. Орлова-Гудім.

Реферат. У пониззі р. Дніпро (Херсонська обл.), у тому числі, на території Національного природного парку "Нижньодніпровський" у 2020 р. виявлено шість локалітетів Elodea nuttallii. В статті представлені перші достовірні знахідки цієї чужорідної водної рослини північноамериканського походження у Степовій зоні України. Раніше вид фіксували на Поліссі (Київ) та у Лісостепу (Київська, Полтавська та Черкаська області). Для виявлених локалітетів вказано географічні координати, глибину, на якій фіксували рослини, та субстрат донних відкладів. Узагальнено дані щодо еколого-ценотичних особливостей виду на території України. Відмічено, що цілком вірогідним є поширення Elodea nuttallii, як потенційно інвазійної в регіоні рослини, не лише у пониззі Дніпра, а й на всіх водосховищах Дніпровського каскаду.

Ключові слова: флористична знахідка, чужорідні види, Elodea 